\title{
HUBUNGAN PEMBERIAN TUGAS RUMAH (PR) JENIS PRACTICE EXERCISE/LATIHAN TERHADAP HASIL BELAJAR KOGNITIF SISWA PADA MATA PELAJARAN IPS KELAS V SEKOLAH DASAR NEGERI 6 DEDAI TAHUN PELAJARAN 2017/2018
}

\author{
Julita, Eliana Yunitha Seran, Imanuel Sairo Awang. \\ STKIP Persada Khatulistiwa Sintang, JL. Pertamina-Sengkuang-Sintang. \\ Email: Julhitajul@mail.com
}

\begin{abstract}
Abstrak
Tujuan dari penelitian ini adalah untuk mengetahui adanya hubungan antara pemberian tugas rumah (PR) jenis practice exercise/latihan dengan hasil belajar kognitif siswa pada mata pelajar IPS SDN 6 Dedai tahun pelajaran 2017/2018. Metode yang digunakan dalam penelitian ini adalah metode kuantitatif dengan bentuk penelitian korelasional. Populasi keseluruhan berjumlah 20 siswa dan semuanya dijadikan sampel penelitian. Teknik pengambilan sampel menggunakan teknik sampling jenuh. Data yang digunakan dalam penelitian ini diperoleh dari instrumen angket dan nilai ulangan umum semester satu.Berdasarkan analisis data, ditemukan koefisien korelasi atau $t_{\text {hitung }}$ sebesar 0,746 lebih besar dari $t_{\text {tabel }}$ 0,444. Artinya ada hubungan, hal ini dipertegas dengan hasil perhitungan koefisien determinasi sebesar 0,557. Artinya 55,7 \% hasil belajar IPS siswa dipengaruhi oleh pemberian tugas rumah (PR). Kemudian untuk mengetahui signifikasi dari hubungan tersebut, dilakukan uji t Ketentuannya jika $r_{\text {hitung }}>r_{\text {tabel }}$, maka Ha diterima, dan Ho ditolak. Hasil Uji $t$ tersebut menunjukan bahwa harga $t_{\text {hitung }}$ lebih besar daripada $t_{\text {tabel }}(4,759>$ 2,101), sehingga Ha diterima dan Ho ditolak. Artinya hubungan tersebut signifikan. Kesimpulan dari penelitian ini adalah terdapat hubungan yang signifikan antara pemberian tugas rumah (PR) jenis practice exercise/latihan dengan hasil belajar kognitif siswa pada mata pelajar IPS SDN 6 Dedai tahun pelajaran 2017/2018.
\end{abstract}

Kata Kunci: Pemberian tugas rumah Jenis Practice Exersice/Latihan, Hasil Belajar Kognitif

\begin{abstract}
The purpose of this study was to determine the correlation between giving homework assignments (PR) types of practice exerciseltraining with students' cognitive learning outcomes to the eyes of social studies students SDN 6 Dedai 2017/2018 school year. The method used in this study is a quantitative method with a form of correlational research. The total population is 20 students and all of them are used as research samples. The sampling technique uses a saturated sampling technique. The data used in this study were obtained from questionnaire instruments and semester 1 general test scores. Based on data analysis, it was found that the correlation coefficient or tcount was 0.746 greater than t table 0.444. That means there is a correlation, this is confirmed by the calculation of the determination coefficient of 0.557. This means that 55.7\% of students' social studies learning outcomes are influenced by giving homework. Then to find out the significance of the correlation, a t-test is carried out. Provisions if $r$ count $>r$ table, then Ha is accepted, and Ho is rejected. The t test results show that the price of tcount is greater than table (4,759>2,101), so Ha is accepted and Ho is rejected. This means that the correlation is significant. The conclusion of this study is that there is a significant correlation between giving home assignments $(P R)$ the type of practice exercise/training with student cognitive learning outcomes in the eyes of social studies students SDN 6 Dedai in the academic year 2017/2018.
\end{abstract}

Keywords: Home Assignment Type of Practice Exercise, Cognitive Learning Outcomes 
Julita, Eliana Yunitha Seran, Imanuel Sairo Awang

\section{PENDAHULUAN}

Pendidikan menjadi pilihan utama dalam membentuk kepribadian yang mandiri serta kedewasaan dan kematangan pada tingkatan yang lebih tinggi karena Pendidikan mempunyai posisi strategis dalam rangka meningkatkan kualitas dan mutu sumber daya manusia oleh sebab itu pendidik/guru yang merupakanfasilitatorsekaligus motivator dalam pembelajaranharus berkualitas serta profesional agar dapat membelajarkan siswa.

Namun lemahnya proses pembelajaran dalam dunia pendidikan menanamkan kebiasaan yang mengarah pada kemalasan belajar. Siswa hanya datang kesekolah, dengan mengabaikan tujuan utamanya untuk belajar dan melupakan tugasnya sebagai pelajar. Hal ini dapat dilihat dengan berkurangnya perhatian siswa terhadap pelajaran disekolah, kelalaian dalam mengerjakan tugas yang diberikan guru, kelalaian dalam mengerjakan pekerjaan rumah, permintaan penundaan ulangan harian dan sebagainya. Kebiasaan belajar yang tidak baik ini berefek pada hasil belajar yang rendah. Hal yang sama terjadi di SDN 6 Dedai.

Untuk mengatasi masalah tersebut guru menerapkan suatu metode agar dapat memaksimalkan proses belajar siswa. Metode tersebut adalah metode pemberian tugas rumah. Metode ini biasanya diterapkan bila materi pembelajaran terlalu banyak, siswa kurang efektif dalam belajar disekolah, hasil belajar siswa kurang memuaskan/dibawah KKM (belum tuntas).

Penerapan metode ini biasanya berupa latihan soal-soal, penyelesaian LKS, merangkum, menggambar peta, menghafal dan lain-lain. Dengan metode ini diharapkan siswa dapat mengejar ketertingalannya, meningkatkan hasil belajarnya, lebih displin dan lebih bertanggungjawab terhadap tugas dan sekolah. Setelah penerapan metode ini siswa menunjukan kedisiplinan yang baik dalam belajar, siswa menunjukan sikap yang lebih positif terhadap tugas dan sekolah, dan hasil belajar siswa menunjukan peningkatan dari sebelumnya.

Hasil belajar merupakan perubahan pada tingkat pengetahuannya/kognitif, perubahan pada pola tingkahlakunya/ afektif, serta bertambahnya keterampilan yang dimiliki/psikomotorik setelah mengalami proses belajar dan latihan secara terus menerus. Berdasarkan pernyataan diatas maka pemberian tugas rumah (PR) bagi siswa tidak boleh diabaikan oleh guru jika ingin memaksimalkan hasil belajar siswa. pemberian tugas rumah memberikan kontribusi yang cukup besar untuk hasil belajar siswa, karena siswa didorong untuk belajar disekolah dan dimaksimalkan 
Julita, Eliana Yunitha Seran, Imanuel Sairo Awang

dirumah melalui PR. Jadi selain melibatkan guru dan siswa pelaksanaan metode pemberian tugas rumah (PR) juga akan melibatkan orang tua siswa karena pelaksanaanya dilakukan dirumah bukan disekolah. Jika ketiga komponen utama yaitu guru, siswa dan orangtua siswa ikut terlibat secara aktif dalam pelaksanaan metode ini maka akan mampu memaksimalkan hasil belajar siswa. terutama untuk hasil belajar kognitif penerapan metode ini akan sangat berpengaruh karena siswa didorong untuk meningkatkan usaha belajar, dan latihan secara teratur serta dengan disiplin diri yang baik. Dalam penelitian ini hasil belajar diukur dari nilai ulangan umum IPS siswa kelas $\mathrm{V}$ semester satu tahun pelajaran 2017/2018.

Rumusan masalah dalam penelitian ini adalah. (1). Bagaimana Pemberian Tugas Rumah (PR) jenis Practice Exercise/latihanPada Mata Pelajaran IPS Kelas V SDN 6 Dedai Tahun Pelajaran 2017/2018? (2). Seberapa besar Hasil Belajar Kognitif Siswa Pada Mata Pelajaran IPS Kelas V SDN 6 Dedai Tahun Pelajaran 2017/2018? (3). Apakah terdapat hubungan yang signifikan antara Pemberian Tugas Rumah (PR) jenis Practice Exercise/latihandengan Hasil Belajar Kognitif Siswa pada mata Pelajaran IPS Kelas V SDN 6 Dedai Tahun Pelajaran 2017/2018?
Sedangkan tujuan dari penelitian ini adalah (1). Mengetahui Pemberian Tugas Rumah (PR) jenis Practice Exercise/latihanSiswa pada mata Pelajaran IPS Kelas V SDN 6 Dedai Tahun Pelajaran 2017/2018. (2). Mengetahui seberapa besar Hasil Belajar Kognitif Siswa pada mata Pelajaran IPS Kelas V SDN 6 Dedai Tahun Pelajaran 2017/2018. (3). Mengetahui hubungan yang signifikan antara Pemberian Tugas Rumah (PR) jenis Practice Exercise dengan Hasil Belajar Kognitif Siswa pada mata Pelajaran IPS Kelas V SDN 6 Dedai Tahun Pelajaran 2017/2018.

\section{METODE PENELITIAN}

Metode penelitian yang digunakan dalam penelitian ini adalah metode penelitian korelasional/hubungan dengan pendekatan kuantitatif karena data yang didapat berhubungan dengan angka yang memungkinkan digunakan teknik analisis statistik. Populasi dalam penelitian ini adalah seluruh siswa kelas V SDN 6 Dedai, yang berjumlah 20 siswa. teknik pengambilan sampel yang digunakan adalah nonprobability sampling dengan cara sampling jenuh, artinya seluruh populasi digunakan sebagai sampel. Variabel dalam penelitian ini adalah pemberian tugas rumah $(\mathrm{PR})$ jenis practice exercis/latihan sebagai variabel independe/bebas (X), dan hasilbelajar 
Julita, Eliana Yunitha Seran, Imanuel Sairo Awang

kognitif siswa pada mata pelajar IPS sebagai variabel dependen/terikat $(\mathrm{Y})$. Teknik pengumpulan data menggunakan teknik komunikasi tidak langsung dan teknik dokumenter. Alat pengumpulan data menggunakan lembar angket atau koesioner dan dokumen hasil belajar IPS siswa kelas V SDN 6 Dedai. Pengujian validitas angket variabel pemberian tugas rumah (PR) jenis practice exersice/latihan menggunakan rumus korelasi product moment dari sugiyono (2012: 228) dan pengujian reliabelitas menggunakan rumus spearman brown dari sugiyono (2015: 190). Rumus uji validitas menggunakan rumus korelasi product moment dari sugiyono (2012: 228) sebagai berikut.

\section{Rumus Uji Validitas}

$r_{x y}=\frac{\mathrm{n} \cdot \sum \mathrm{xy}-\left(\sum \mathrm{x}\right)\left(\sum \mathrm{y}\right)}{\sqrt{\left\{\mathrm{n} \cdot \sum \mathrm{x}^{2}-\left(\sum \mathrm{x}\right)^{2}\right\}\left\{\mathrm{n} \cdot \sum \mathrm{y}^{2}-\left(\sum \mathrm{y}\right)^{2}\right\}}}$

Keterangan:

$$
\begin{aligned}
& \mathrm{r}_{\mathrm{xy}}=\text { koefisien korelasi } \\
& \mathrm{x}=\text { skor butir soal (jawaban } \\
& \mathrm{y}=\text { skor } \begin{array}{c}
\text { total (jawaban } \\
\text { responden) }
\end{array} \\
& \mathrm{x}^{2}=\text { skor butir soal setelah } \\
& \mathrm{y}^{2}={ }^{\text {skor }} \text { total setelah } \\
& \sum \mathrm{x}=\text { jumlah skor butir soal } \\
& \sum \mathrm{y}=\text { jumlah skor total } \\
& \sum x=\begin{array}{l}
\text { jumlah hasil perkalian } \\
\text { dari skor butir dan } \\
\text { skor total }
\end{array} \\
& \mathrm{N} \quad=\underset{\text { diteliti }}{\text { jumlah sampel yang }}
\end{aligned}
$$

Rumus pengujian reliabelitas menggunakan rumus Spearman Brown dari sugiyono (2015: 190) adalah sebagai berikut.

\section{Rumus Uji Reliabilitas}

$r_{i}=\frac{2 \cdot r b}{1=r b}$

\section{Keterangan:}

$r_{i}:$ Reliabilitas internal seluruh instrument

$\mathrm{r}_{\mathrm{b}}$ : korelasi product moment antara belahan pertama dan belahan kedua

Analisi data dimulai dari uji prasyarat yaitu uji normalitas dan uji linieritas regresi. Uji normalitas dilakukan untuk menentukan apakah data tersebut berdistribusi normal atau tidak. Jika tidak normal maka analisi parametris tidak dapat digunakan. Uji normalitas data menggunakan rumus dasar Chi Kuadrat dari Sugiyono (2012: 107) sebagai berikut.

\section{Rumus Uji Normalitas Data}

$x^{2}=\sum_{i=1}^{k} \frac{\left(f_{o}-f_{h}\right)^{2}}{f_{h}}$

Keterangan:

$\begin{array}{rlrl}\mathrm{X}^{2}= & \text { Chi Kuadrat } & \\ \mathrm{f}_{\mathrm{o}}= & \text { Frekuensi/jumlah data hasil } \\ & \text { observasi } & \\ \mathrm{f}_{\mathrm{h}}= & \text { Jumlah/frekuensi } & \text { yang } \\ & \text { diharapkan (persentase luas } \\ & \text { tiap bidang dikalian dengan } \mathrm{n}) \\ \mathrm{f}_{\mathrm{o}}-\mathrm{f}_{\mathrm{h}}= & \text { Selisih data } \mathrm{f}_{\mathrm{o}} \text { dengan } \mathrm{f}_{\mathrm{h}}\end{array}$


Julita, Eliana Yunitha Seran, Imanuel Sairo Awang

Uji linearitas dilakukan untuk melihat apakah garis regresi antara variabel $\mathrm{X}$ dan variabel $\mathrm{Y}$ membentuk garis regresi atau tidak. Jika tidak linear maka analisis regresi tidak dapat dilanjutkan. Uji linieritas regresi menggunakan Rumusrumus yang digunakan dalam uji linearitas dari Sugiyono (2010: 265) berikut ini.

\section{Rumus Uji Regresi}

$$
\begin{array}{ll}
\mathrm{JK}(\mathrm{T}) & =\sum \mathrm{Y}^{2} \\
\mathrm{JK}(\mathrm{A}) & =\frac{\left(\sum \mathrm{Y}\right)^{2}}{\mathrm{n}} \\
\mathrm{JK}(\mathrm{a} \mid \mathrm{b}) & =\mathrm{b}\left\{\sum \mathrm{XY}-\frac{\left(\sum \mathrm{X}\right)\left(\sum \mathrm{Y}\right)}{n}\right\} \\
\mathrm{JK}(\mathrm{S}) & =\mathrm{JK}(\mathrm{T})-\mathrm{JK}(\mathrm{a})-\mathrm{JK}(\mathrm{a} \mid \mathrm{b}) \\
\mathrm{JK}(\mathrm{TC}) & =\sum \mathrm{x}_{\mathrm{i}} \\
\mathrm{JK}(\mathrm{G}) & =\mathrm{JK}(\mathrm{S})-\mathrm{JK}(\mathrm{TC}) \\
\text { keterangan } & : \\
\mathrm{JK}(\mathrm{T}) & =\text { Jumlah kuadrat total } \\
\mathrm{JK}(\mathrm{a}) & =\text { Jumlah kuadrat koefisien a } \\
\mathrm{JK}(\mathrm{a} \mid \mathrm{b}) & =\text { Jumlah kuadrat regresi (a|b) } \\
\mathrm{JK}(\mathrm{S}) & =\text { Jumlah kuadrat sisa } \\
\mathrm{JK}(\mathrm{TC}) & =\text { Jumlah kuadrat tuna cocok } \\
\mathrm{JK}(\mathrm{G}) & =\text { Jumlah kuadrat galat }
\end{array}
$$

Menyusun persamaan regresi, menurut Sugiyono (2015: 261), persamaan regesi dapat digunakan untuk melakukan prediksi seberapa tinggi nilai variabel dependen bila nilai variabel indevenden dimanipulasi (dirubah-rubah). Secara umum persamaan regresi sederhana (dengan satu prediktor) dapat dirumuskan sebagai berikut.

\section{Rumus Persaman Regresi Sederhana}

$$
\widehat{Y}=a+b X
$$

Keterangan:

$$
=\text { nilai yang diprediksikan }
$$

$$
\begin{aligned}
& \mathrm{a}=\text { Konstanta atau bila nilai } \mathrm{X}=0 \\
& \mathrm{~b}=\text { Koefisien regresi } \\
& \mathrm{X}=\text { Nilai variabel indevenden }
\end{aligned}
$$

Analisis Data Penelitian. Pertama Analisis korelasi dimaksudkan untuk melihat seberapa besar hubungan yang terjadi antara variabel $\mathrm{X}$ dan variabel $\mathrm{Y}$ menggunakan rumus korelasi product moment dari Sugiyono (2015: 228) sebagai berikut.

\section{Rumus Korelasi Product Moment}

$$
\mathrm{r}_{\mathrm{xy}}=\frac{\sum \mathrm{xy}}{\sqrt{\left(\sum \mathrm{x}^{2}\right)\left(\sum \mathrm{y}^{2}\right)}}
$$

Keterangan :

$r_{x}$. Koefisien korelasi antara variabel

y : $\mathrm{x}$ dan variabel $\mathrm{y}$

$\mathrm{X}:\left(\mathrm{X}_{\mathrm{i}}-\overline{\mathrm{X}}\right)$

$\mathrm{Y}:\left(\mathrm{y}_{\mathrm{i}}-\overline{\mathrm{y}}\right)$

Analisis Koefisien Determinan dimaksudkan untuk melihat dan memberikan interpretasi seberapa besar sumbangan variabel $\mathrm{X}$ terhadap variabel $\mathrm{Y}$ menggunakan rumus uji determinan dari sugiyono berikut ini.

\section{Rumus Analisis Determinan}

$\mathrm{KD}=\mathrm{r}_{\mathrm{xy}}^{2} \mathrm{x} 100 \%$

\section{Keterangan :}

$\mathrm{KD}$ : nilai koefisien determinan

$\mathrm{r}_{\mathrm{xy}}$ : koefisien korelasi

Uji Hipotesis (Uji t), merupakan teknik analisis untuk membandingkan satu variabel bebas. Teknik ini digunakan untuk menguji apakah nilai tertentu berbeda secara signifikan atau tidak dengan rata- 
Dunia Anak: Jurnal Pendidikan Anak Usia Dini, 1 (2), November 2018

Julita, Eliana Yunitha Seran, Imanuel Sairo Awang

rata sebuah sampel Menggunakan rumus

uji t dari Sugiyono (2015: 259) berikut ini.

\section{Rumus Uji Hipotesis (Uji T)}

$t=\frac{\mathrm{r} \sqrt{\mathrm{n}-2}}{\sqrt{1-\mathrm{r}^{2}}}$

Keterangan:

$\mathrm{t}=$ nilai $t_{\text {hitung }}$

$\mathrm{r}=$ koefisien korelasi

$\mathrm{n}=$ ukuran sampel

\section{HASIL DAN PEMBAHASAN}

Deskripsi umum hasil penelitian memaparkan rata-rata, median modus, standar deviasi, varian, skor minimum, skor maksimum dari variabel pemberian tugas rumah (PR) jenis practice exersice/latihan dengan Variabel Hasil Belajar Kognitif Siswa. Hasilnya disajikan pada tabel berikut.

Tabel 1 Gambaran variabel pemberian tugas rumah (PR) jenis practice exersice/latihan.

\begin{tabular}{|c|c|c|c|c|c|}
\hline Variabel & Mean & Median & Modus & Standard Deviasi $\left(\mathrm{S}^{2}\right)$ & Varians $(\mathrm{S})$ \\
\hline $\begin{array}{l}\text { Pemberian Tugas } \\
\text { Rumah (PR) jenis } \\
\text { practice exersice }\end{array}$ & 103,5 & 103,5 & 102,83 & 7,452 & 55,53 \\
\hline Skor Maksimal & & & & 115 & \\
\hline Skor Minimal & & & & 90 & \\
\hline Skor Rata-Rata & & & & 102,7 & \\
\hline Presentase & & & & $82,16 \%$ & \\
\hline
\end{tabular}

Berdasarkan tabel diatas secara umum, gambaran variabel pemberian tugas rumah $(\mathrm{PR})$ jenis practice exersice/latihan dikategorikan baik dengan

Belajar Kognitif Siswa skor rata-rata 102,7 dan diperoleh presentase rata-rata sebesar $82,16 \%$ berdasarkan data angket dari 20 responden. Kesimpulannya pemberian tugas rumah (PR) jenis practice exersice/latihan di SDN

6 Dedai termasuk dalam kategori baik Tabel 2 Gambaran Variabel Hasil

\begin{tabular}{|c|c|c|c|c|c|}
\hline Variabel & Mean & Median & Modus & Standard Deviasi $\left(\mathrm{S}^{2}\right)$ & Varians $(S)$ \\
\hline $\begin{array}{l}\text { Hasil Belajar } \\
\text { Kognitif Siswa. }\end{array}$ & 68,35 & 65,5 & 67,83 & 16,695 & 278,73 \\
\hline Nilai Tertiggi & & & & 90 & \\
\hline Nilai Terendah & & & & 45 & \\
\hline Nilai Rata-Rata & & & & 68,5 & \\
\hline Presentase & & & & $68,5 \%$ & \\
\hline
\end{tabular}


Berdasarkan tabel 2. Gambaran umum variabel hasil belajar kognitif siswa berdasarkan nilai ulangan umum semester satu pada pembelajaran IPS kelas V SDN
6 Dedai tahun pelajaran 2017/2018 mendapat nilai rata-rata sebesar 68,5 , masuk dalam kategori cukup/sedang berdasarkan tolak ukur hasil belajar yang digunakan dibawah ini

Tabel 3. Tolak Ukur Kategori Penilaian Rata-rata Hasil

Belajar kognitif siswa

\begin{tabular}{ccl}
\hline Skor Akhir & Keputusan & \multicolumn{1}{c}{ Kategori } \\
\hline $80-100$ & Berhasil & A (Sangat Baik) \\
\hline $70-79$ & Berhasil & B (Baik) \\
\hline $60-69$ & Berhasil & C (Cukup) \\
\hline $50-59$ & Belum berhasil & D (Kurang) \\
\hline $0-49$ & Belum berhasil & E (Sangat Kurang) \\
\hline
\end{tabular}

Berdasarkan tabel 4. Kesimpulannya adalah hasil belajar kognitif siswa berdasarkan nilai ulangan umum semester satu pada pembelajaran IPS kelas V SDN 6 Dedai tahun pelajaran 2017/2018 adalah berhasil dengan kategori C (cukup).

\section{Hasil Uji Normalitas}

Hasil uji normalitas berdasarkan perhitungan dengan rumus chi kuadat ditemukan harga chi kuadrat hitung sebesar $=8,36$ harga tersebut selanjutnya

Tabel 3 Hasil Rekapitulasi Uji Normalitas

\begin{tabular}{ccccc}
\hline Variabel & $\begin{array}{c}\text { Harga chi } \\
\text { kuadrad tabel }\end{array}$ & $\begin{array}{c}\text { Harga chi kuadrad } \\
\left(\mathrm{x}^{2)} \text { hitung }\right.\end{array}$ & Kondisi & Keputusan \\
\hline $\mathrm{X}$ & 11,070 & 8,36 & $\begin{array}{c}\text { chi kuadrad hitung }< \\
\text { chi kuadrad tabel } \\
\text { atau } 8,36<11,070\end{array}$ & $\begin{array}{c}\text { Data berdistribusi } \\
\text { normal }\end{array}$ \\
\hline
\end{tabular}

Berdasarkan tabel 3 diatas harga chi dari harga chi kuadrat tabel atau 8,36 < kuadrat hitung yang ditemukan lebih kecil 
Julita, Eliana Yunitha Seran, Imanuel Sairo Awang

pemberian tugas rumah (PR) jenis practice exersice/latihan tersebut adalah normal.

Oleh karena itu, penggunaan statistik parametris untuk pengujian hipotesis dapat dilanjutkan

\section{Hasil Uji Linearitas}

Salah satu asumsi dari analisis regresi adalah linearitas, maksudnya untuk melihat bahwa garis regresi antara $\mathrm{X}$ dan Y membentuk garis linear atau tidak Jika tidak linear maka analisis regresi tidak dapat dilanjutkan. Pengujian linearitas menggunakan rumus uji lineritas regresi dari Sugiyono (2010 : 265). Menguji linearitas menggunakan regresi sederhana yang dilanjutkan dengan uji F. Dengan kaidah keputusan sebagai berikut: jika $\mathrm{F}$ hitung < Ftabel dengan taraf kesalahan $5 \%, \mathrm{~F}$ tabel $(12,6)=4,00$. maka $H_{a}$ : diterima dan jika $\mathrm{F}_{\text {hitung }}>\mathrm{F}_{\text {tabel }}$ maka $H_{a}$ : ditolak. Hasil rekapitulasi perhitungan uji regresi linear adalah sebagai berikut

Tabel 5 Hasil Analisis Uji Linearitas Data

\begin{tabular}{|c|c|c|c|c|c|}
\hline Sumber Varian & Dk & JK & KT & $\mathrm{F}$ & \multirow{2}{*}{ keterangan } \\
\hline Total & 20 & 96698 & 96698 & & \\
\hline Koefisien a & 1 & 93845 & 93845 & \multirow{3}{*}{19,62} & \multirow{5}{*}{$\begin{array}{l}\text { Ternyata } F_{\text {hitung }}<F_{\text {tabel }} \\
2,51<4,00, \\
\text { maka data berpola linear }\end{array}$} \\
\hline Regresi a|b & 1 & 1488 & 1488 & & \\
\hline Sisa & 18 & 1365 & 75,83 & & \\
\hline Tuna Cocok & 12 & 1138 & 94,83 & \multirow{2}{*}{2,51} & \\
\hline Galat & 6 & 227 & 37,83 & & \\
\hline
\end{tabular}

Berdasarkan tabel 5, ternyata $\mathrm{F}_{\text {hitung }}$ lebih kecil dari $\mathrm{F}_{\text {tabel }}$ atau 2,51 $<4,00$, maka data untuk variabel pemberian tugas rumah (PR) jenis practice exersice/latihan dengan variabel hasil belajar kognitif Siswa berpola linier, sehingga dapat disimpulkan bahwa analisis uji regresi dapat dilanjutkan.

\section{Analisis Persamaan Regresi}

$\widehat{Y}=a+b X$

$$
\widehat{Y}=-54,4+1,2 \mathrm{X}
$$

$\widehat{Y}=-54,4+1,2 \cdot 10=-42,4$
Berdasarkan hasil perhitungan diatas harga regresi yang ditemukan adalah $\widehat{Y}=-$ $54,4+1,2 \mathrm{X}$. Dari persamaan diatas dapat diartikan bahwa, bila pemberian tugas rumah jenis practie exersice/latihan (X) ditetapkan 10 maka nilai individu dalam variabel Y akan bertambah 10 menjadi 42,4 atau bila nilai yang diperoleh siswa adalah 10 maka nilai rata-rata hasil belajar Variabel Y akan bertambah sebesar 10,2. (nilai 10 adalah skor minimal yang dapat diperoleh siswa dalam PR dan 100 adalah 
Julita, Eliana Yunitha Seran, Imanuel Sairo Awang

skor maksimal yang dapat diperoleh dalam

PR). ini artinya bahwa ada hubungan yang positif antara pemberian tugas rumah jenis practie exersice/latihan dengan hasil belajar kognitif siswa.

\section{Analisis Korelasi Sederhana}

Hasil analisis korelasi/ hubungan antara pemberian tugas rumah (PR) jenis practice exersice/latihan dengan hasil belajar kognitif siswa pada mata pelajar IPS Kelas V SDN 6 Dedai Tahun Pelajaran 2017/2018 menggunakan rumus korelasi product moment dari Sugiyono (2015: 228) adalah sebagai berikut:

$$
\begin{aligned}
r_{x y} & =\frac{\sum x y}{\sqrt{\left(\sum x^{2}\right)\left(\sum y^{2}\right)}} \\
& =\frac{1285}{\sqrt{1038.2858}} \\
& =\frac{1285}{\sqrt{2966604}} \\
& =\frac{1285}{1722,383} \\
& =0,746059=0,746
\end{aligned}
$$

Analisi korelasi menunjukan terdapat hubungan antara pemberian tugas rumah (PR) jenis practice exercise/Latihan dengan hasil belajar kognitif siswa pada mata pelajaran IPS dengan ditemukannya koefisien korelasi sebesar 0,746 Nilai koefisien korelasi kemudian diinterpretasi ke dalam nilai $r$ seperti berikut.

Tabel 6. Interpretasi Koefisien Korelasi Nilai r

\begin{tabular}{cc}
\hline Interval Koefisien & Tingkat Hubungan \\
\hline $0,80-1,000$ & Sangat Kuat \\
$0,60-0,799$ & Kuat \\
$0,40-0,599$ & Cukup Kuat \\
$0,20-0,399$ & Rendah \\
$0,00-0,199$ & Sangat Rendah \\
\hline
\end{tabular}

Nilai koefisien korelasi yang ditemukan sebesar 0,746 kemudian diinterpretasi ke dalam nilai $\mathrm{r}$ pada tabel 6 . Berdasarkan tabel 6 koefisien korelasi sebesar 0,746 berada pada rentang antara 0,60 - 0,799 dan berada pada kategori tingkat hubungan kuat. Jadi kesimpulanya hubungan antara pemberian tugas rumah (PR) jenis practice exercise/Latihan dengan hasil belajar kognitif siswa pada mata pelajaran IPS adalah kuat.

\section{Analisis Uji Determinan}

Hubungan yang kuat antar variabel tersebut dipertegas oleh hasil perhitungan koefisien determinasi yang dianalisis menggunakan rumus perhitungan koefisien determinan sebagai berikut.

$\mathrm{KD}=\mathrm{r}_{\mathrm{xy}}{ }^{2} \mathrm{x} 100 \%$

Keterangan :

KD : nilai koefisien determinan

$\mathrm{r}_{\mathrm{xy}}:$ koefisien korelasi 
Julita, Eliana Yunitha Seran, Imanuel Sairo Awang

$\mathrm{KD}=0,746^{2}=0,557$

$\mathrm{KD}=0,557 \times 100 \%=55,7 \%$

Berdasarkan hasil perhitungan diatas diperoleh nilai koefisien determinan sebesar $\mathrm{r}_{\mathrm{xy}}^{2}=0,557 \times 100 \%=55,7 \%$. Artinya $55,7 \%$ perubahan dari variabel y ditentukan oleh variabel $\mathrm{x}$ dan sisanya $44,3 \%$ ditentukan oleh faktor lain misalnya suasana kelas, cara guru mengajar dll.

\section{Pengujian Hipotesis (Uji T)}

Selain menganalisis kuatnya hubungan dan menganalisis besarnya kontribusi variabel $\mathrm{X}$ terhadap $\mathrm{Y}$, analisis juga dilanjutkan dengan uji t untuk melihat apakah tingkat signifikansi/beratinya hubungan tersebut berlaku terhadap seluruh sampel penelitian. Hasil pengujian hipotesis yang ditemukan kemudian dibandingkan dengan harga t tabel sebesar 2,101 untuk kesalahan 5\% uji dua fihak dan $\mathrm{dk}=\mathrm{n}-2=20-2=18$. Ketentuannya jika harga $t_{\text {hitung }}>\mathrm{t}_{\text {tabel }}$ berarti Ha diterima dan Ho ditolak dan sebaliknya jika harga $\mathrm{t}_{\text {hitung }}<\mathrm{t}_{\text {tabel }}$, berati Ha ditolak dan Ho diterima Berikut adalah hasil analisis uji hipotesi

$t=\frac{\mathrm{r} \sqrt{\mathrm{n}-2}}{\sqrt{1-\mathrm{r}^{2}}}$

Keterangan:

$$
\begin{aligned}
& \mathrm{t}=\text { nilai } t_{\text {hitung }} \\
& \mathrm{r}=\text { koefisien korelasi } \\
& \mathrm{n}=\text { ukuran sampel }
\end{aligned}
$$

$$
\begin{aligned}
t & =\frac{0,746 \sqrt{20-2}}{\sqrt{1-0,746^{2}}} \\
& =\frac{0,746 \sqrt{18}}{\sqrt{1-0,557}} \\
& =\frac{0,746 \sqrt{18}}{\sqrt{0,443}} \\
& =\frac{0,746 \cdot 4,243}{0,665} \\
& =\frac{3,165}{0,665}=4,759
\end{aligned}
$$

Rekapitulasi hasil perhitungan uji t dpat dilihat pada tabel 7 dibawah ini.

Tabel 7 Rekapitulasi Hasil Uji Hipotesis Variabel X Dan Y

\begin{tabular}{ccccc}
\hline Hipotesis & $\mathrm{t}_{\text {hitung }}$ & $\mathrm{t}_{\text {tabel }}$ & Kondisi & Keputusan \\
\hline X terhadap Y & 4,759 & 2,101 & $\begin{array}{c}\mathrm{t}_{\text {hitung }}>\mathrm{t}_{\text {tabel }} \\
\text { atau } \\
4,759>2,101\end{array}$ & $\begin{array}{c}\text { Hubungan } \\
\text { Signifikan }\end{array}$ \\
\hline
\end{tabular}

Jadi berdasarkan uji t yang dilakukan diperoleh harga $t_{\text {hitung }}>\mathrm{t}_{\text {tabel }}$ atau 4,759> 2,101, sehingga $\mathrm{Ha}$ diterima dan Ho ditolak. Jadi, kesimpulannya secara parsial atau individual variabel pemberian tugas rumah (PR) jenis practice exersice/latihan
(X)memiliki hubungan yang signifikan dengan hasil belajar kognitif siswa (Y) pada mata pelajaran IPS kelas V SDN 6 Dedai tahun pelajaran 2017/2018. Hasil penelitian ini sejalan dengan hasil penelitian yang dilakukan oleh Febriani 
Julita, Eliana Yunitha Seran, Imanuel Sairo Awang

Widyaningsih yang berjudul hubungan antara pemberian tugas rumahdengan hasil belajar IPS siswa kelas 4 SDNRawasari 03 pagiJakarta pusat hasil penelitiannya menunjukkan adanya hubungan antara pemberian tugas rumah dengan hasil belajar IPS siswa dengan nilai Korelasinya $\mathrm{t}_{\text {hitung }}$ sebesar 0,718 .

\section{KESIMPULAN DAN SARAN}

Berdasarkan hasil penelitian tentang hubungan pemberian tugas rumah $(\mathrm{PR})$ jenis practice exercise/Latihan terhadap hasil belajar kognitif siswa pada mata pelajaran IPS Kelas V Sekolah Dasar Negeri 6 Dedai TahunPelajaran 2017/2018, maka dapat disimpulkan sebagai berikut .

Berdasarkan data angket pemberian tugas rumah jenis practice exersice/latihan yang disebarkan kepada 20 responden/siswa kelas $\mathrm{V}$ diperoleh diperoleh kesimpulan bahwa PR yang diberikan sudah baik dengan skor rata-rata 102,7 dan presentase rata-rata sebesar $82,16 \%$ yang berada pada kategori baik.

hasil belajar kognitif siswa berdasarkan nilai ulangan umum semester satu pada pembelajaran IPS kelas V SDN 6 Dedai tahun pelajaran 2017/2018 masuk dalam kategori cukup/sedang. dengan mendapat nilai rata-rata sebesar68,5 dengan nilai tertinggi 90 dan nilai terendah 45, dan masuk dalam kategori baik sehingga dapat dibuat kesimpulan bahwa hasil belajar siswa kelas V SekolahDasarNegeri6 Dedai Tahun Pelajaran 2017/2018 sudah cukup, namun dapat ditingkatkan lagi dengan pemberian tugas rumah (PR) yang lebih baik lagi.

Analisi korelasi menunjukan terdapat hubungan yang kuat antara pemberian tugas rumah (PR) jenis practice exercise/Latihan dengan hasil belajar kognitif siswa pada mata pelajaran IPS dengan ditemukannya koefisien korelasi sebesar 0,746, dan dipertegas oleh hasil perhitungan koefisien determinan sebesar 0,557 atau 55,7\%. Artinya 55,7\% perubahan dari variabel Y ditentukan oleh variabel $\mathrm{X}$ dan $44,3 \%$ ditentukan oleh faktor lain. Selain Kuatnya hubungan yang terjadi serta besarnya sumbangan pengaruh variabel $\mathrm{X}$ terhadap variabel $\mathrm{Y}$ hubungan tersebut juga signifikan/berarti dengan ditemukannya nilai koefisien korelasi $t_{\text {hitung }}$ sebesar 4,759 lebih besar dari dengan $t_{\text {tabel }}$ sebesar 2,101. artinya hubungan yang terjadi antara pemberian tugas rumah (PR) jenis practice exersice/latihan dengan hasil belajar kognitif siswa pada mata pelajaran IPS kelas V SDN 6 Dedai Tahun Pelajaran 2017/2018 adalah signifikan/berarti, sehingga pemberian tugas rumah (PR) jenis practice exercise/Latihan perlu dipertimbangkan dan diperhatikan untuk meningkatkan motivasi belajar siswa 
Julita, Eliana Yunitha Seran, Imanuel Sairo Awang

melalu latihan dan praktek secara langsung terutama dirumah.

Pemberian tugas rumah (PR) yang diberikan oleh guru memberikan konstribusi dan mempengaruhi yang cukup besar terhadap hasil belajar kognitif siswa jadi dukungan dan peran serta dari berbagai pihak perlu diperhatikan dan ditingkatkan secara maksimal. Berdasarkan kesimpulan tersebut tentang hubungan pemberian tugas rumah (PR) jenis practice exercise/Latihan terhadap hasil belajar kognitif siswa pada mata pelajaran IPS Kelas V Sekolah Dasar Negeri 6 Dedai TahunPelajaran 2017/2018, peneliti memberikan saran sebagai berikut:

1. Bagi siswa sebaiknya tingkatkan disiplin diri dalam belajar terutama mengerjakan PR. Perbanyak latihan dengan mengerjakan soal-soal dirumah, PR dikerjakan sendiri.

2. Bagi guru sebaiknya berikan inovasi dan variasi dalam memberikan tugas rumah untuk siswa agar siswa tidak bosan, melakukan

prosedurpenilaiansecaraterprogram

(formatifdansumatif),

melakukanfeedback/umpan

baliksegerakepadasiswa, melakukan evaluasi pada setiap tugas/PR yang diberikan serta berikan penghargaandaninsentifuntuk mendorongmunculnyaperilakupositif siswa.

3. Bagi orang tua. Berikan perhatian dan motivasi kepada siswa dalam belajar atau mengerjakan tugas di rumah. Dampingi anak waktu belajar. Sediakan ruangan yang nyaman untuk anak belajar. Berikan dukungan moral bagi anak ketika dia berhasil ataupun gagal.

4. Bagipeneliti selanjutnya sebaiknya sempurnakan hasil penelitian ini terutama menambah indikator penelitian sebanyak teori yang dijadikan referensi, dan gunakan hasil penelitian sebelumnya sebagai referensi.

\section{DAFTAR RUJUKAN}

Premata, F. M. (2010). "Hubungan Keseriusan Mengerjakan Pekerjaan Rumah (PR) Terhadap Hasil Belajar Ilmu Statika dan Tegangan Siswa Program Studi Teknik Bangunan Smk N 1 Seyegan" Skripsi. Yogyakarta : Fakultas Teknik Sipil Dan Perencanaan Universitas Negeri Yogyakarta.

Http://id.portalgaruda.org. diakses 10 juni 2017).

Sadirman, A. M. (2014). Interaksi dan motivasi belajar mengajar. Jakarta: PT RajaGrafindo Persada.

Sugiyono.(2010).MetodePenelitianKuantit atif, Kualitatifdan $R \quad \& \quad D$. Bandung: Alfabet. 
Julita, Eliana Yunitha Seran, Imanuel Sairo Awang

Sugiyono.(2015).MetodePenelitianKuantit

atif, Kualitatifdan $R \quad \& \quad D$.

Bandung: Alfabet.

Sugiyono.(2010). Statistik Untuk

Pendidikan. Bandung: Alfabet.

Widyaningsih, F. (2011). "Hubungan

Antara Pemberian Tugas Rumah

Dengan Hasil Belajar IPS Siswa

Kelas 4 Sdn Rawasari 03 Pagi

Jakarta Pusat" Skripsi. Jakarta:

Universitas Muhammadiyah Prof.

Dr.Hamka.(Http://id.portalgaruda.

org. diakses 10 juni 2017). 